\title{
Giant abdominal recurrent liposarcoma with multiple histological types
}

\author{
L. Álvarez-Llanoํ, J. Martín-Gil ${ }^{1}$, A. García-Marín ${ }^{1}$, T. Sánchez-Rodríguez¹ , M. A. Martínez-Izquierdo², \\ L. E. Bernardos-García ${ }^{1}$, M. D. Pérez-Díaz ${ }^{1}$ and F. Turégano-Fuentes ${ }^{1}$
}

Services of ${ }^{\prime}$ General Surgery II and ${ }^{2}$ Pathology. Hospital General Universitario Gregorio Marañón. Madrid, Spain

Liposarcomas are rare malignant mesenchymal tumors (less than $1 \%$ of all malignant tumors) (1) with an incidence of 2-3/100.000 new cases per year. There are more than 50 types of sarcomas, and liposarcomas are the most frequent (2). Its diagnosis is difficult because of nonspecific symptoms, such as increased abdominal perimeter or abdominal pain. The treatment of choice is surgical resection (3).

\section{CASE REPORT}

A 56 years patient old male diagnosed of retroperitoneal liposarcoma with low-grade malignancy and 15 years of evolution, who was operated on our center on 8 occasions with various patterns of recurrence. The first intervention took place in 1990, and he presented a liposarcoma grade I.

The patient was admitted to Internal Medicine at another hospital with a respiratory infection. Physical examination revealed a painless abdominal mass in the left abdomen. A chest X-ray showed elevation of the left diaphragm, blood test disclosed an iron deficiency anemia. Abdominal CT scan showed a 26 x $20 \times 13 \mathrm{~cm}$ mass in the left abdomen in close contact with the mesentery, on heterogeneous appearance with areas of fat density and dense clusters; the mass was encapsulated and displaced all the adjacent structures, there was another mass in left renal bed of $6 \mathrm{x} 4 \mathrm{~cm}$ with similar characteristics, and a small third one at the right suprarenal area.

The patient was referred to our department of surgery for assessment. He was diagnosed with recurrent giant liposarcoma, which was confirmed intraoperatively. A radical resetion was performal with splenectomy for loco-regional invasion. The pathology report was of a mass of $5.35 \mathrm{~kg}$, which was classified as liposarcoma (Fig. 1) with areas of low grade (lipoma-like) and high grade (malignant fibrohistiocitoma, rhabdomyosarcoma, fibrosarcoma) of malignancy.

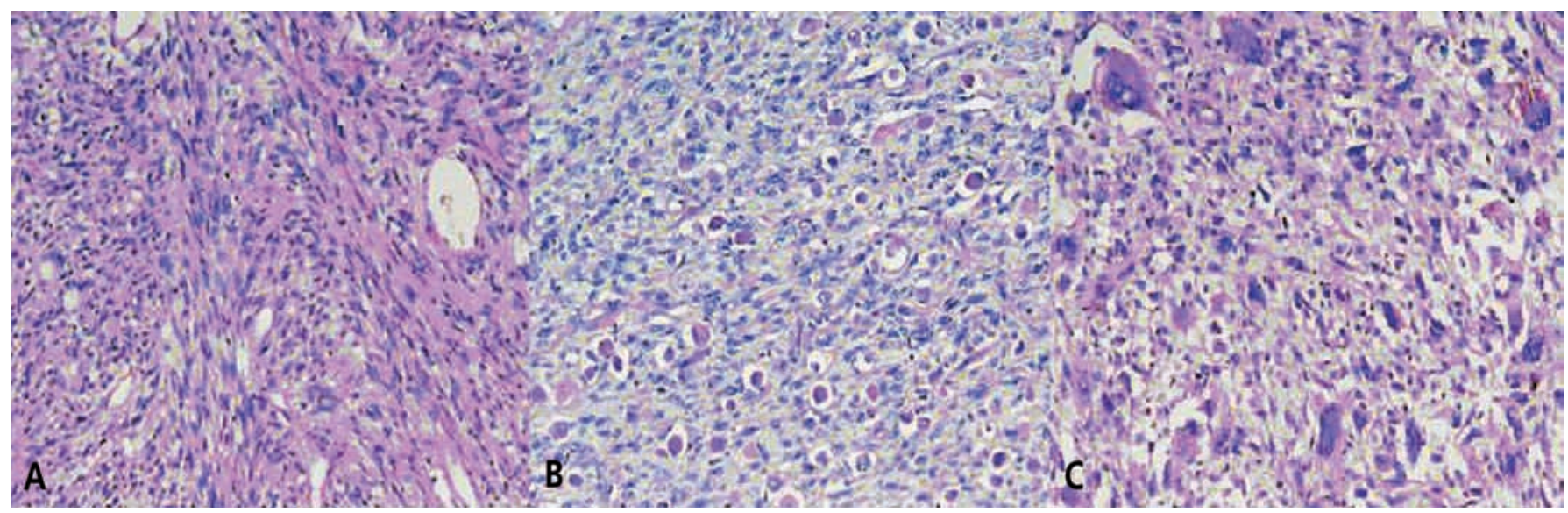

Fig. 1. Specimen histology: A. Fusocellular cells, hyperchromatic nuclei, prominent nucleoli and scant cytoplasm in a pattern of bone fish (fibrosarcoma). B. Areas of differentiation of rhabdomyosarcoma formed by polygonal cells with prominent cytoplasm, and eccentric eosinophilic. C. Bizarre giant cells were observed, with eosinophilic cytoplasm and pleomorphic nuclei (malignant fibrohistiocitoma).

Histología de la pieza: A. Células fusocelulares, núcleo hipercromático, nucléolo prominente y escaso citoplasma, en un patrón de espina de pescado (fibrosarcoma). B. Áreas de diferenciación rabdomiosarcomatosa, formadas por células poligonales con citoplasma prominente, excéntrico y eosinófilo. C. Se observan células gigantes bizarras, con citoplasma eosinófilo y núcleo pleomórfico (fibrohistiocitoma maligno). 


\section{DISCUSSION}

Sarcomas can occur in all age groups, but most often present in young adults with a peak of maximum incidence at 50 years. With regard to its location, 60\% develop in the limbs, the torso in $30 \%$ (of which $40 \%$ are retroperitoneal, "RPS") and the remaining $10 \%$ in head and neck ${ }^{3}$. Liposarcomas account for 7 to $28 \%$ of RPS. There are four different pathological types of liposarcomas:

- Well differentiated, which has two forms, lipoma like and sclerosing, they have little metastatic power and a high affinity for sites such as the retroperitoneum, mediastinum and subcutaneous tissue.

- Dedifferentiated or high grade, with great ability to metastatise and an aggressively behaviors especially to the lungs.

- Myxoid, the most common, with a preference for the lower limbs.

-Pleomorphic, with many different types of cells.

In our case there was an association of several histological subtypes, with each recurrence being more aggressive histologically, although there were no signs of distant metastases $(3,4)$. The histologic diagnosis is based on the presence of fatty tissue cells and immunohistochemical techniques like S-100, desmin, CD117 and cytokeratins, markers of different types of cells (5), and the determination of changes in the region 12q13-15 that produce MDM2 and CDK4 gene mutations, involved in the malignancy of the different subtypes of cells.

The treatment of choice is radical resection, requiring in some cases adjuvant chemotherapy and radiotherapy according to the stage, but recurrence is the rule (6).

\section{REFERENCES}

1. Delaloge S, Yovine A, Taamma A, Riofrio M, Brain E, Raymond E, et al. Ecteinascidin-743: A marine-Deived compound in advanced, pretreated sarcoma patiens, preliminary evidence of activity. J Clin Oncol 2001; 19: 1248-55.

2. Pascual Samaniego M, González Fajardo JA, Fernández de la Gándara F, Calleja Escudero J, Sanz Lucas FJ, Fernández del Busto E, et al. Liposarcoma retroperitoneal gigante. Actas Urolol Esp 2003; 27: 640-4.

3. Calleja Subirán MC, Hernández Gutiérrez FJ, López Elzaurdia C, Revestido García R, et al. Subtipos histológicos de liposarcoma: presentación de cuatro casos. An Med Interna 2007; 24: 179-84.

4. Ferrero Doria R, Moreno Pérez F, Huertas Valero E, García Víctor F, Gassó Matoses M, Calatrava Gadea S, et al. Liposarcoma retroperitoneal calcificado. Actas Urolol Esp 2004; 28: 234-7.

5. Álvarez Domínguez T, Gómez Plata E, Guevara López GB, Soriano-Rosas J, Carrera-González E, Durán-Padilla MA, et al. Tumores retroperitoneales. Revisión de 5 años en material de autopsia. Rev Med Hosp Gen Mex 2004; 67: 78-82.

6. Echenique Elizondo M, Amondarain Arratíbel JM, et al. Liposarcoma retroperitoneal gigante. Cir Esp 2005; 77: 293-5. 